\title{
Serum phospholipid fatty acid profile and dietary intake in an adult Mediterranean population with cystic fibrosis
}

\author{
Gabriel Olveira ${ }^{1 *}$, Antonio Dorado ${ }^{2}$, Casilda Olveira ${ }^{2}$, Alicia Padilla ${ }^{2}$, Gemma Rojo-Martínez $^{1}$, \\ Eva García-Escobar ${ }^{1}$, Inmaculada Gaspar $^{2}$, Montserrat Gonzalo ${ }^{1}$ and Federico Soriguer ${ }^{1}$ \\ ${ }^{1}$ Endocrinology and Nutrition Service, 4a planta, Pabellón A, Carlos Haya University Hospital, Avenida Carlos Haya, \\ Malaga 29010, Spain \\ ${ }^{2}$ Pneumology Service, Carlos Haya University Hospital, Malaga, Spain
}

(Received 12 May 2005 - Revised 19 October 2005 - Accepted 20 October 2005)

\begin{abstract}
The relative importance of the usual diet in serum phospholipids in subjects with cystic fibrosis (CF) has been poorly studied. To compare the fatty acid profile in serum phospholipids from adult CF subjects with that of healthy subjects, and determine the role of the normal diet in this profile, we studied thirty-seven adult CF subjects with stable pulmonary disease and thirty-seven healthy controls matched for age, sex and nutritional status. A dietary questionnaire was obtained, anthropometric data were recorded, and the fatty acid profile measured by GLC. Compared with the controls, the percentages of myristic, palmitoleic and stearic acids and total MUFA were significantly higher in the CF group, and DHA, linoleic acid, total PUFA and $n-6$ fatty acids were significantly lower in the CF group. The CF subjects with worse pulmonary function and with pancreatic insufficiency had significantly lower levels of linoleic and $n-6$ fatty acids. The total energy intake was significantly higher in the CF subjects, although the energy distribution in the CF subjects and the controls was not different for the carbohydrates, lipids and proteins. No differences were detected in fat intake for MUFA (51 (SD 4) v. 52 (SD 4) \%) or saturated fatty acids (33.5 (SD 5) v. 31.2 (SD 3.8) \%), but the PUFA were slightly lower in the CF subjects (15.4 (SD 4.5) v. 17.4 (SD 4.2) \%; $P=0.02$ ). The usual dietary intake of fatty acids by adult CF subjects does not appear to explain the difference in the fatty acid profile compared with controls. This suggests an abnormal fatty acid metabolism in $\mathrm{CF}$ subjects.
\end{abstract}

Cystic fibrosis: Serum phospholipid fatty acids: Diet

Individuals with cystic fibrosis (CF) often have abnormal levels of essential fatty acid (EFA) in serum, plasma and blood cell membranes, as well as in tissue biopsies (Christophe \& Robberecht, 2001; Freedman et al. 2004). Compared with the general population, the most important feature in $\mathrm{CF}$ subjects is the low level of linoleic acid and DHA and the relative increase in the percentage of monoenoic and eicosatrienoic fatty acids (Lepage et al. 2002; Freedman et al. 2004). This anomalous profile has been seen not only in CF subjects with poor fat absorption or who are malnourished, but also in $\mathrm{CF}$ subjects with exocrine pancreatic insufficiency with an adequate energy intake and with normal fat absorption (Roulet et al. 1997), as well as in CF subjects with no exocrine pancreatic insufficiency and with a good nutritional status (Lai et al. 2000; Freedman et al. 2004). Although not supported by some experimental animal models (Werner et al. 2004), it has been suggested that these findings may be caused by an intrinsic defect in fatty acid metabolism, together with the CF transmembrane conductance regulator (CFTR) gene (Freedman et al. 2004), and that the effect is more pronounced in CF subjects with more severe mutations (Strandvik et al. 2001). Together with this defect there also appears to exist an accel- erated metabolism of arachidonic acid, which could contribute to both low linoleic acid concentration and to the inflammation (Carlstedt-Duke et al. 1986; Christophe \& Robberecht, 2001). As serum phospholipids are rich in EFA and are in dynamic equilibrium with tissue phospholipids, the fraction of the different fatty acid in this serum lipid class is often used as a marker of the usual intake and to determine the EFA status.

The importance of the daily diet on plasma or serum phospholipid fatty acids in subjects with CF has been poorly studied. Several studies have examined just individual dietary aspects (Tomezsko et al. 1992; Kawchak et al. 1996; Mora et al. 1996; Anthony et al. 1998; White et al. 2004) or only laboratory variables (fatty acid profile) (Christophe et al. 1994; Lloyd-Still et al. 1996; Benabdeslam et al. 1998; Strandvik et al. 2001). Most studies which have analysed the phospholipid profile and diet together have been undertaken in countries where the usual diet differs greatly from that of the Mediterranean region (Roulet et al. 1997; Lai et al. 2000; Lepage et al. 2002), were within the context of nutritional intervention studies (Lepage et al. 2002; De Vizia et al. 2003), included mainly children (Lai et al. 2000; Lepage et al. 2002) or adolescents

Abbreviations: CF, cystic fibrosis; CFF, Cystic Fibrosis Foundation; CFTR, cystic fibrosis transmembrane conductance regulator; EFA, essential fatty acid; FEV1, forced expiratory volume in $1 \mathrm{~s}$; FVC, forced vital capacity.

* Corresponding author: Dr Gabriel Olveira-Fuster, fax +34 9522867 04, email gabrielm.olveira.sspa@juntadeandalucia.es 
(Roulet et al. 1997; De Vizia et al. 2003), failed to analyse the type of dietary fat (Lai et al. 2000; Lepage et al. 2002) or even lacked a control group of healthy subjects (Lai et al. 2000).

The aim of the present study was to compare the fatty acid profile in serum phospholipids from adult subjects with $\mathrm{CF}$ with that from healthy subjects, as well as the role of the normal Mediterranean diet in this fatty acid profile.

\section{Material and methods}

The present study included individuals meeting the diagnostic criteria for $\mathrm{CF}$ according to the Cystic Fibrosis Foundation (CFF) consensus statement (Cystic Fibrosis Foundation, 1997), and who were being periodically followed up at the Adult Cystic Fibrosis Unit, Carlos Haya University Hospital, Malaga, Spain. All the CF subjects were older than 16 years of age, had completed puberty, and had been in a clinically stable condition for 3 months before the present study, during which time they had not been admitted to hospital, nor had they had any respiratory exacerbations or weight change greater than $3 \%$ of their body weight. The CF subjects were informed about the aims of the study and gave their written consent. A control group was composed of the same number of healthy individuals, matched for sex, age and nutritional status, selected from the Pizarra nutritional study in the province of Malaga (Soriguer et al. 2002).

A $7 \mathrm{~d}$, a prospective dietary questionnaire was administered to all the subjects in their homes. An experienced dietitian provided detailed instructions to the participants about weighing and recording all the food consumed. The same dietitian reviewed the questionnaire with the subjects to resolve any ambiguities. The dietary data were entered into a personal computer equipped with a nutrient content software package with composition tables for Spanish food (Moreiras et al. 1992; Mataix, 1995). The fat composition of the fish consumed was taken from the data of Soriguer et al. (1997). The composition of any nutritional supplements taken was also included in the database.

Comparison of the energy intake of all CF subjects and controls with the estimated daily energy requirement was made with the equation proposed by the Sociedad Española de Nutrición Comunitaria (Arija et al. 2001). The energy intake of the CF subjects was also compared with the daily energy requirement as calculated by the CFF equation (Ramsey et al. 1992).

Measurements were made in all CF subjects and controls of weight and height, to calculate the BMI, and the upper-arm circumference. At the end of the $7 \mathrm{~d}$ period, blood was drawn, and the serum was immediately separated and stored at $-70^{\circ} \mathrm{C}$ until the measurements were made. The fatty acid composition of the serum phospholipids was made by extraction of the serum fat with chloroform-methanol $(2: 1, \mathrm{v} / \mathrm{v})$ and butylated hydroxytoluene $(0.025 \%)$, and phospholipid separation by TLC $(200 \times 200 \times 1 \mathrm{~mm}$ plates of silica gel $60 \mathrm{G}$; solvents were hexane-ether-acetic acid; $80: 20: 2$, by vol.). Fatty acid methyl esters were formed by heating the extracted fat for $30 \mathrm{~min}$ with $0.61 \mathrm{M}-\mathrm{H}_{2} \mathrm{SO}_{4}$ in anhydrous methanol. After extraction with hexane, the fatty acid methyl esters were analysed in a Hewlett-Packard chromatograph (HP 4890; Hewlett Packard, Wilmington, DE, USA), equipped with a flame ionisation detector and using a BPX75 fused-silica capillary column (SGE, Villebon, France) (Soriguer et al. 2003).
During the course of a routine follow-up examination in the CF subjects, a blood test was done and measurements made of clotting, basic biochemical parameters (by an autoanalyser), albumin, and fat-soluble vitamins A, D and E. A $72 \mathrm{~h}$ stool sample was collected for the quantitative measurement of faecal fat and $\mathrm{N}$ by means of a spectrophotometric technique (near IR reflectance analysis) (Picarelli et al. 1995). Three measurements of the skinfold thickness of the triceps were made by the same investigator using a Holtain-type caliper, and the mean of the three measurements was assigned. Percentiles were estimated from the reference values for the Spanish population (Alastrue et al. 1988).

The CF subjects underwent simple and forced spirometry, according to the Spanish Society of Respiratory Diseases and Thoracic Surgery (Sanchis et al. 1989), and measurements were made of the forced vital capacity (FVC) and the forced expiratory volume in $1 \mathrm{~s}$ (FEV1). The values were expressed as a percentage of the theoretical value for individuals of the same sex, age, weight and height in a reference population (Roca et al. 1982).

The severity of CF was assessed with the Bhalla score (Bhalla et al. 1991), based on computerised tomography of the chest and the clinical and radiological modified National Institutes of Health score (Sockrider et al. 1994). CFTR genotypes were classified into two groups (mild or severe) according to the reported phenotypic effects of the published mutations and on the primary mechanism of defective CFTR according to the expected effect of their mutation on CFTR protein function (Welsh \& Smith, 1993). The presence of two severe mutations was considered to reflect a severe genotype and the coexistence of two mild mutations or one severe and one mild was considered to reflect a mild genotype. The CF subjects classified as having a severe genotype ( $n$ 18) had the following combinations: $\Delta \mathrm{F} 508 / \Delta \mathrm{F} 508$ ( $n$ 7), G542X/G542X ( $n$ 4), $\Delta$ F508/G542X (n 3), $\Delta$ F508/N1303K (n 1), $\Delta \mathrm{F} 508 / 1717-1 \mathrm{G}->\mathrm{A}(n$ 1), $\Delta \mathrm{F} 508 / \mathrm{Q} 890 \mathrm{X}$ ( $n$ 1) or $\Delta$ F508/2184insA ( $n$ 1). Data analysis was performed with SPSS for Windows, version 11.0 (SPSS Inc, Chicago, IL, USA). Results are expressed as mean values with standard deviations. For comparison between groups the two-tailed unpaired Mann-Whitney test was used for quantitative variables and the $\chi^{2}$ test for qualitative variables. The Spearman rank linear correlation coefficient was calculated to describe the interrelationships between two measurements. A $P$ value of $<0.05$ was regarded as significant.

\section{Results}

A total of thirty-seven CF subjects and thirty-seven controls were studied (fifteen men and twenty-two women in each group). Table 1 summarises the main clinical characteristics of the CF subjects. The system mainly involved at diagnosis of CF was digestive in seventeen $(46 \%)$ subjects (three had meconium ileus) and respiratory in $18(49 \%)$. In the other two subjects $(5 \%)$, CF was diagnosed from a family history. Pancreatic insufficiency was present in $70 \%$ of the CF subjects; these received pancreatic enzyme replacement and fatsoluble vitamin supplementation, with median daily doses of $3000 \mu \mathrm{g}$ vitamin $\mathrm{A}, 20 \mu \mathrm{g}$ vitamin $\mathrm{D}$, and $200 \mathrm{mg}$ vitamin E. The dose supplementation was assessed on an individual basis according to plasma levels. Vitamin $\mathrm{K}$ was only 
Table 1. Clinical characteristics of the subjects ( $n 37)$ with cystic fibrosis (Mean values and standard deviations)

\begin{tabular}{|c|c|c|c|c|}
\hline & Mean & SD & $n$ & Percentage \\
\hline Age at diagnosis (years) & 12 & 10 & & \\
\hline $\begin{array}{l}\text { Modified National } \\
\text { Institutes of Health score* }\end{array}$ & 76 & 16 & & \\
\hline Bhalla score $\dagger$ & 15 & 4 & & \\
\hline Fat absorption (\%) & 92 & 6 & & \\
\hline FEV1 (\%)‡ & 64 & 27 & & \\
\hline FVC $(\%) \ddagger$ & 71 & 21 & & \\
\hline \multicolumn{5}{|l|}{ Genetic study } \\
\hline Homozygotes DF508 & & & 7 & $18 \cdot 9$ \\
\hline Heterozygotes DF508 & & & 18 & 48.6 \\
\hline Others & & & 12 & $32 \cdot 4$ \\
\hline Severe genotype & & & 18 & $48 \cdot 6$ \\
\hline Mild genotype & & & 19 & $51 \cdot 4$ \\
\hline Pancreatic insufficiency & & & 26 & 70 \\
\hline Presence of diabetes & & & 7 & 19 \\
\hline $\begin{array}{l}\text { Impaired glucose tolerance } \\
\text { or impaired fasting glucose }\end{array}$ & & & 4 & 11 \\
\hline $\mathrm{BMI}<18.5 \mathrm{~kg} / \mathrm{m}^{2}$ & & & 7 & 19 \\
\hline Albumin $<3.5 \mathrm{~g} / \mathrm{l}$ & & & 5 & $14 \cdot 3$ \\
\hline Low levels of vitamin $\mathrm{D} \S$ & & & 4 & $10 \cdot 8$ \\
\hline Low levels of vitamin $A \S$ & & & 1 & $2 \cdot 7$ \\
\hline Low levels of vitamin $\mathrm{E} \S$ & & & 0 & 0 \\
\hline
\end{tabular}

FVC, forced vital capacity; FEV1; forced expiratory volume in $1 \mathrm{~s}$.

* Sockrider et al. (1994).

† Bhalla et al. (1991).

$\ddagger$ Expressed as a percentage of the theoretical value in a reference population.

$\S$ Normal values: vitamin $\mathrm{E}(\alpha$-tocopherol), 11.6-46 $\mu \mathrm{mol} / \mathrm{l}$; vitamin A (retinol), $0.7-$ $1.75 \mu \mathrm{mol} / \mathrm{l}$; vitamin $25 \mathrm{OH}-\mathrm{D}, 22.5-92 \mathrm{nmol} / \mathrm{l}$.

prescribed for $\mathrm{CF}$ subjects with uncontrolled pancreatic insufficiency or who were receiving a long course of antibiotic therapy. The CF subjects without exocrine pancreatic insufficiency received supplementary vitamin E $(200 \mathrm{mg} / \mathrm{d})$. Seven CF subjects $(19 \%)$ had diabetes mellitus but only three required pharmacological therapy. Colonisation with Haemophilus influenzae had been detected in $59 \%$, Pseudomonas (aeruginosa or cepacia) in $75 \%$ and Staphylococcus aureus in $81 \%$. All the CF subjects routinely received advice on maximising dietary energy, protein and fat intake. Only eleven (30\%) CF subjects consumed nutritional supplements, which provided an average of $20 \%$ of the total energy (2628 (SD 1167) kJ (628 (SD 279) kcal)/d). No patient took supplements enriched with $n-3$ fatty acids. The CF subjects consumed a mean of $114 \%$ of the estimated energy requirement according to the $\mathrm{CFF}$ equation; seven $\mathrm{CF}$ subjects consumed less than $90 \%$, four CF subjects consumed from 90 to $100 \%$ and 26 $\mathrm{CF}$ subjects consumed over $100 \%$ of the energy estimated by this equation. Table 2 summarises the clinical data and the results of the dietary survey of the CF subjects and the controls. There were no differences in age, sex or anthropometric measurements. In the $\mathrm{CF}$ subjects the total energy intake was significantly higher, both in absolute terms and after correcting for body weight. Nevertheless, the respective energy distribution in the $\mathrm{CF}$ subjects and the controls of carbohydrates (45.3 (SD 5.6) v. 45.6 (SD 4.6) \%), lipids (39.2 (SD 5.3) v. 39.6 (SD 4.6) \%) and proteins (15 (SD 2.8) v. 14.3 (SD 2.1) \%) was not different. There were no differences in fat intake with regard to MUFA (51 (SD 4) v. 52 (SD 4) \%), saturated fatty acids (33.5 (SD 5) v. 31.2 (SD 3.8) \%) or $n$-3 fatty acids $(1.2(\mathrm{SD} 0.4) v .1 .2(\mathrm{SD} 0.4) \%)$, but there was
Table 2. Clinical characteristics and results of the dietary survey in cystic fibrosis (CF) subjects and controls

(Mean values and standard deviations)

\begin{tabular}{|c|c|c|c|c|}
\hline & \multicolumn{2}{|c|}{ CF subjects ( $n 37$ ) } & \multicolumn{2}{|c|}{ Controls (n 37) } \\
\hline & Mean & SD & Mean & SD \\
\hline Age (years) & 24.5 & 9 & 25 & 6 \\
\hline Weight (kg) & $57 \cdot 5$ & 12 & 59 & 8 \\
\hline Height (cm) & 162 & 8 & 165 & 9 \\
\hline BMI $\left(\mathrm{kg} / \mathrm{m}^{2}\right)$ & $21 \cdot 8$ & 4 & $21 \cdot 8$ & 2 \\
\hline $\begin{array}{l}\text { Brachial } \\
\quad \text { circumference }(\mathrm{cm})\end{array}$ & 24 & $3 \cdot 6$ & 25 & 2 \\
\hline Energy intake $(\mathrm{kJ} / \mathrm{d})$ & 13269 & 3014 & $10927^{\star \star \star}$ & 2935 \\
\hline $\operatorname{EER}(\%)$ & 132 & 27 & 108 & 24 \\
\hline EER-CFF (\%) & 114 & 25 & - & - \\
\hline $\begin{array}{l}\text { Energy intake } \\
(\mathrm{kJ} / \mathrm{kg} \text { per } \mathrm{d})\end{array}$ & 236 & 59 & $184 \cdot 4^{\star \star \star}$ & $44 \cdot 5$ \\
\hline Carbohydrates $(\mathrm{g} / \mathrm{d})$ & 358 & 114 & $298^{\star *}$ & 85 \\
\hline $\begin{array}{l}\text { Carbohydrates } \\
\text { (energy \%) }\end{array}$ & 45 & $5 \cdot 6$ & $45 \cdot 6$ & $4 \cdot 6$ \\
\hline Lipids (g/d) & 136 & 36 & $115^{\star \star}$ & 34 \\
\hline Lipids (energy \%) & 39 & 5 & 39.6 & 4.6 \\
\hline$\%$ SFA & 33 & 5 & 31 & 4 \\
\hline$\%$ MUFA & 51 & 4 & 51 & 4 \\
\hline$\%$ PUFA & 15 & 4.5 & $17^{*}$ & 4 \\
\hline$\% n-3 F A$ & $1 \cdot 2$ & 0.4 & 1.2 & 0.4 \\
\hline$\% n-6$ FA & $14 \cdot 2$ & 4 & $16^{\star *}$ & 4 \\
\hline Proteins (g/d) & 116 & 31 & $92^{\star \star \star}$ & 26 \\
\hline Protein (energy \%) & 15 & $2 \cdot 8$ & 14 & 2 \\
\hline Alcohol $(g / d)$ & 1.3 & 4 & 1.7 & 3 \\
\hline Alcohol (energy \%) & 0.3 & 0.8 & 0.4 & 0.8 \\
\hline
\end{tabular}

EER, estimated daily energy requirement; EER-CFF: estimated daily energy requirement according to the equation of the Cystic Fibrosis Foundation (Ramsey et al. 1992); energy \%, percentage of daily energy intake; SFA, saturated fatty acid; FA, fatty acid.

Mean values were significantly different from those of the CF subjects (MannWhitney test): ${ }^{*} P<0.05,{ }^{* *} P<0.01,{ }^{* \star *} P<0.001$.

a slightly lower intake of total PUFA (15.4 (SD 4.5) v. 17.4 (SD $4.2) \%$ ) and $n-6$ fatty acids ( $14 \cdot 2$ (SD 4) v. 16 (SD 4) \%).

Table 3 shows the fatty acid composition of the serum phospholipids in $\mathrm{CF}$ subjects and controls. The percentages

Table 3. Fatty acid composition of serum phospholipids in cystic fibrosis (CF) subjects and controls (mol/100 mol)

(Mean values and standard deviations)

\begin{tabular}{|c|c|c|c|c|}
\hline & \multicolumn{2}{|c|}{ CF subjects ( $n$ 37) } & \multicolumn{2}{|c|}{ Controls ( $n$ 37) } \\
\hline & Mean & SD & Mean & SD \\
\hline SFA (\%) & 53 & 9.5 & $49 \cdot 4$ & $7 \cdot 8$ \\
\hline MUFA (\%) & 15 & $5 \cdot 5$ & $12^{*}$ & 2.5 \\
\hline PUFA (\%) & $31 \cdot 8$ & $5 \cdot 8$ & $38 \cdot 5^{\star *}$ & $6 \cdot 5$ \\
\hline$n-6$ Fatty acids(\%) & $28 \cdot 7$ & 5 & $34^{\star \star}$ & 5 \\
\hline VLC $n-3$ fatty acids (\%) & 3 & 1.7 & $4 \cdot 5^{\star}$ & $1 \cdot 8$ \\
\hline Myristic acid (14:0) (\%) & 1.5 & 0.9 & $0.45^{\star *}$ & 0.5 \\
\hline Palmitic acid (16:0) (\%) & 33 & $5 \cdot 6$ & 35 & 9 \\
\hline Stearic acid (18:0) (\%) & 18 & 5 & $13 \cdot 8^{\star *}$ & 2 \\
\hline Oleic acid (18: $1 n-9)(\%)$ & $12 \cdot 7$ & 3.7 & 11.4 & $2 \cdot 4$ \\
\hline Palmitoleic acid (16:1n-7) & $2 \cdot 4$ & 2 & $0.5^{\star *}$ & 0.5 \\
\hline Linoleic acid (18:2n-6) (\%) & 19 & 4 & $23^{\star \star}$ & 4 \\
\hline Arachidonic acid $(20: 4 n-6)$ & $9 \cdot 6$ & 2 & $10 \cdot 7$ & $2 \cdot 7$ \\
\hline EPA (20:5n-3) (\%) & 0.57 & 0.5 & 0.51 & 0.56 \\
\hline $\mathrm{DHA}(22: 6 n-3)(\%)$ & 2.58 & 1.5 & $4^{\star *}$ & 1.5 \\
\hline
\end{tabular}

SFA, saturated fatty acid; VLC, very-long-chain.

Mean values were significantly different from those of the CF subjects (MannWhitney test): ${ }^{\star} P<0.01,{ }^{* \star} P<0.0001$. 
of myristic, palmitoleic and stearic acids, and total MUFA were significantly higher in the CF subjects, and the percentages of DHA, linoleic, total PUFA, $n-6$ and very-long-chain $n-3$ fatty acids were significantly lower in the CF subjects, compared with the healthy controls.

Table 4 summarises the main clinical characteristics and the profile of the fatty acid composition of serum phospholipids according to the presence or absence of pancreatic insufficiency, the degree of respiratory involvement, the presence of carbohydrate metabolism disorders, the CFTR genotype, the percentage intake compared with that estimated by the CFF equation and according to nutritional status. According to these characteristics, no significant differences were found in the $\mathrm{CF}$ subjects concerning the percentage of energy derived from the various macronutrients (data not shown), with the exception of the percentage from the $n-3$ fatty acids in the subjects with pancreatic insufficiency (1.34 (SD 0.4) $\%)$ compared with those without pancreatic insufficiency $(1.05(\mathrm{SD} 0.2) \%)$, the percentage of total energy from the proteins in the subjects with carbohydrate metabolism disorders and in those without carbohydrate metabolism disorders (16.8 (SD 2) \% v. 14.3 (SD 3) \%), and the severe genotypes $(15.9$ (SD 3) \%) $v$. the mild genotypes (14.1 (SD 2) \%).

The levels of $n-6$ fatty acids and linoleic fatty acid in the serum phospholipids were significantly lower in CF subjects with a FEV1 percentage lower than $50 \%$ compared with $\mathrm{CF}$ subjects who had a higher FEV1 percentage. No significant differences were found in the fatty acid profile depending on the presence or otherwise of chronic colonisation by Pseudomona, Haemophilus or Staphylococcus aureus.

As expected, the dietary MUFA (expressed as a percentage of total energy intake) correlated positively in the controls with the percentage of MUFA in the serum phospholipids ( $r$ $0.376 ; P=0.02)$ and oleic acid $(r \quad 0.356 ; P=0.03)$. The intake of carbohydrates (expressed as a percentage of total energy intake) was inversely correlated with the percentage of monoenoic fatty acids $(r-0.404 ; P=0.013)$, oleic acid $(r$ $-0.36 ; \quad P=0.029)$, DHA $(r-0.34 ; P=0.041)$, EPA $(r$ $-0.34 ; \quad P=0.041)$ and very-long-chain $n-3 \quad(r-0.387$; $P=0 \cdot 018)$ in the serum phospholipids. In the CF subjects, the intake of saturated fatty acids (expressed as a percentage of total energy intake) correlated positively with the percentage of palmitic acid $(r 0.34 ; P=0.041)$, stearic acid $(r 0.34$; $P=0.042)$ and saturated fatty acids $(r 0.34 ; P=0.044)$ and inversely with the percentage of oleic acid $(r-0.33$; $P=0.049)$ and monoenoic fatty acids $(r-0.36 ; P=0.03)$ in the serum phospholipids. Conversely, no statistically significant correlation was found in the $\mathrm{CF}$ subjects between the other components of the diet and the fatty acid composition of the serum phospholipids.

Positive correlations were found in the CF subjects between the fatty acid profile in the serum phospholipids and various anthropometric, spirometric, clinical and radiological parameters. The percentage of linoleic acid in the serum phospholipids correlated positively with weight $(r 0.42 ; P=0.01)$, the brachial circumference $(r 0.33 ; P=0 \cdot 05)$, FEV1 in $\mathrm{ml}(r 0.367$; $P=0.026)$, FEV1 percentage $(r 0.31 ; P=0.05)$ and FVC $(r$ $0.34 ; P=0.037)$. The percentage of $n-6$ in the serum phospholipids correlated positively with weight $(r 0.37 ; P=0.025)$, brachial circumference $(r 0.35 ; P=0.043)$, FEV1 in $\mathrm{ml}(r$ $0.367 ; P=0.025)$, FEV1 percentage $(r 0.32 ; P=0.049)$, FVC
( $r$ 0.35; $P=0.033)$, FVC percentage $(r 0.31 ; P=0.045)$ and the modified National Institutes of Health score $(r \quad 0.31$; $P=0 \cdot 027$ ).

Faecal fat and $\mathrm{N}$ were used as biological markers to validate the data given by the $\mathrm{CF}$ subjects in their dietary questionnaire. Faecal $\mathrm{N}$ correlated significantly with the weight of faecal fat $(r 0.86 ; P=0.0001)$, total energy consumed $(r$ $0.47 ; P=0.01)$ and the intake by weight of carbohydrates $(r$ $0.35 ; P=0.05)$, lipids $(r 0.5 ; P=0.005)$ and proteins $(r 0.43$; $P=0.015)$. The weight of faecal fat correlated positively with total energy consumed $(r 0.35 ; P=0.04)$ and the intake by weight of lipids $(r 0.36 ; P=0.033)$ and proteins $(r 0.42$; $P=0 \cdot 01)$.

\section{Discussion}

The results of the present study show that the serum phospholipid fatty acid profile in adult subjects with $\mathrm{CF}$ is clearly different from those of a control population. Despite these differences, no significant differences were detected between the diet of the CF subjects and the controls with respect to percentage intake of macronutrients. The fraction of the different serum phospholipid fatty acids is often used as a marker of the usual intake and to determine the EFA status. However, the total serum fatty acids or the fractions contained in the triacylglycerols are influenced by recent food intake (during the few hours before blood extraction), as well as by other factors.

In line with previous experimental (Freedman et al. 1999) and human (Strandvik et al. 2001; Freedman et al. 2004) studies, this abnormal profile, therefore, suggests an abnormal turnover of EFA, with an increased release of arachidonic acid, associated with the disease itself via the altered CFTR gene (Carlstedt-Duke et al. 1986). Blockade of the synthesis of DHA or an increased susceptibility to stimulation of cytoplasmic phospholipase A2 could also be involved. As well as changes in fatty acid metabolism, other possible explanations include defects in fatty acid uptake in the intestine or poor absorption of the micronutrients.

Decreased levels of linoleic acid and DHA in plasma, cell membranes and tissues have been found in human subjects (Benabdeslam et al. 1998; Strandvik et al. 2001; Lepage et al. 2002; Freedman et al. 2004). Levels of arachidonic acid have proved more variable in different studies, including plasma or serum values which were either not significantly different from the controls (as occurred in the present study) (Strandvik et al. 2001; Lepage et al. 2002; Freedman et al. 2004), or were slightly decreased (Lloyd-Still et al. 1996; Benabdeslam et al. 1998) or even increased in biopsy material (Freedman et al. 2004). These variable results could be explained by an accelerated metabolism of arachidonic acid (Carlstedt-Duke et al. 1986; Christophe \& Robberecht, 2001).

Unlike a previous report (Strandvik et al. 2001), only the levels of $n-6$ and linoleic acid in the serum phospholipids of the CF subjects were altered, in accordance with the clinical characteristics of the participants. The levels of $n-6$ and linoleic acid were significantly lower in the CF subjects with worse pulmonary function (lower FEV1 percentage) and with pancreatic insufficiency and, to a lesser extent (without reaching significance), in the CF subjects who had severe genotypes and who were malnourished. However, no significant changes in the values of the other fatty acids studied were 


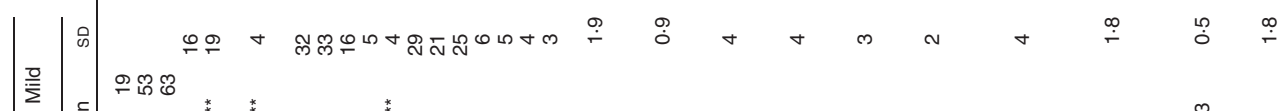

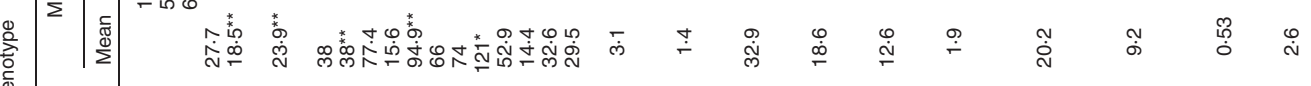

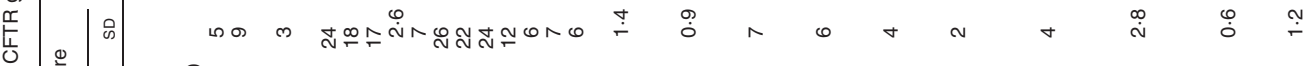

|

D|

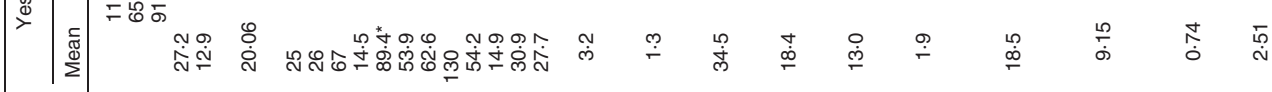

흠

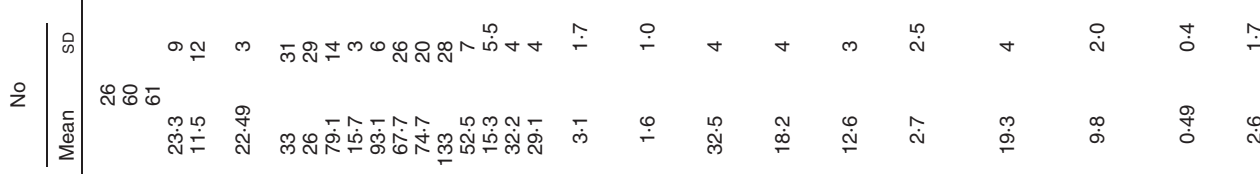

官|

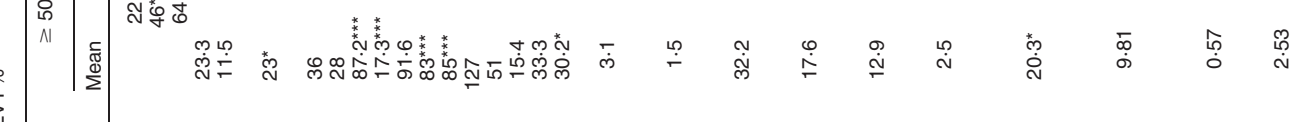

○ी

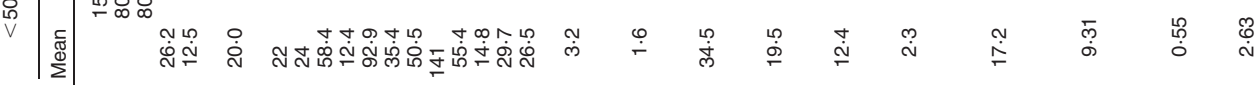

\&

|

$\bar{a}$

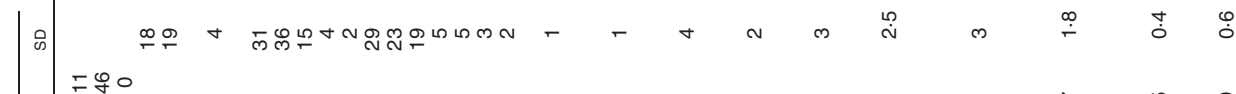

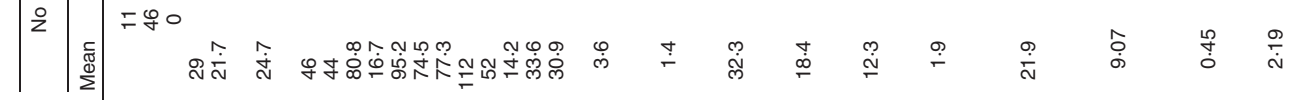


seen in relation to pancreatic insufficiency, the degree of pulmonary involvement, carbohydrate metabolism disorders, energy consumed, nutritional status or even the genotype.

The nutritional status of our CF subjects was generally good; only $19 \%$ had a BMI below $18.5 \mathrm{~kg} / \mathrm{m}^{2}$, and the nutritional parameters were normal in almost all the CF subjects. The concentrations of fatty acids in the serum phospholipids were not significantly different between the undernourished and the well-nourished $\mathrm{CF}$ subjects. This suggests that the abnormal phospholipid profile in the CF subjects was not due to poor fat absorption or malnutrition but rather that these findings are simply aggravating factors or epiphenomena which are usually present in the most severe cases of $\mathrm{CF}$ (Roulet et al. 1997; Lai et al. 2000; Strandvik et al. 2001; Freedman et al. 2004).

The adherence by our $\mathrm{CF}$ subjects to nutritional recommendations was very good. The energy intake of the CF subjects was clearly superior to the controls. Although not all energy consumed is absorbed, the CF subjects consumed over $130 \%$ of the energy recommended for the healthy Spanish population and a mean of $114 \%$ of the energy estimated by the CFF equation, which adjusts for patients with increased energy expenditure and loss. This difference in compliance in comparison with previous studies in children (Tomezsko et al. 1992; Kawchak et al. 1996; Anthony et al. 1998) and adults (White et al. 2004) may be because the current recommendations for individuals with CF (fat-rich diet) are relatively easy to achieve in Spain, as in other Mediterranean countries (De Vizia et al. 2003), since they form part of the daily dietary habits of individuals from this area. The usual dietary intake, both in $\mathrm{CF}$ subjects and in controls, is about $20 \%$ of total energy in the form of MUFA (more than $50 \%$ of total fat intake), mainly olive oil, poor in carbohydrates and slightly increased in proteins. These data are similar to those reported by others in Spain, both for the general population (García-Almeida et al. 2001; Sociedad Española de Nutrición Comunitaria, 2001) and for subjects with other chronic diseases in which diet is an essential element, as for instance diabetes (Diabetes and Nutrition Study Group of the Spanish Diabetes Association, 2004).

Correction of abnormalities in the plasma fatty acid composition in malnourished $\mathrm{CF}$ subjects has been reported when additional energy was provided (Parsons et al. 1988). Nevertheless our data do not confirm this concept. In fact, the CF subjects who consumed more than $100 \%$ of the energy estimated by the CFF equation (a mean of $143 \%$ of the energy recommended for the healthy Spanish population) had levels of fatty acids in the serum phospholipids that were not significantly different to those of the CF subjects who consumed less than $100 \%$.

The intake of fish, which was not high, was not significantly different between the $\mathrm{CF}$ subjects and the controls. The mean consumption of $n-3$ fatty acids was just $1 \mathrm{~g} / \mathrm{d}$ (approximately $1 \%$ of the total dietary fatty acids). Nevertheless, modifying the fatty acid profile of serum phospholipids in CF subjects probably requires supplementing the usual diet with higher levels of $n$-3 fatty acids (Freedman et al. 1999; Beckles et al. 2003; De Vizia et al. 2003) and it may also be necessary to combine them with $\gamma$-linolenic acid (Christophe \& Robberecht, 2001). The scarce correlations in the dietary survey with the fatty acid composition of serum phospholipids in the $\mathrm{CF}$ subjects strengthens the suggestion that the abnormal profile is barely modified with the usual non-supplemented diet. In fact, the strong correlation found between data from the dietary questionnaire and the content in faecal fat and $\mathrm{N}$ validates the correct collection and analysis of the data in the dietary questionnaire.

In conclusion, the fatty acid profile in serum phospholipids from adult subjects with CF is clearly different from that of healthy subjects. This difference is not explained by diet, suggesting an abnormal fatty acid metabolism in subjects with CF. The present study opens the door for clinical trials to assess the effectiveness and possible adverse effects of dietary interventions aimed at obtaining a desirable EFA status.

\section{Acknowledgements}

The present study was partly financed by a grant from the Consejería de Salud de la Junta de Andalucía (02/ 150) and by a grant from the Instituto de Salud Carlos III, Metabolism and Nutrition Network RCMYN (C03/08), Spain. The authors thank Ian Johnstone for the English language version of the manuscript.

\section{References}

Alastrue A, Rull M, Camps I, Ginesta C, Melus MR \& Salva JA (1988) Nuevas normas y consejos en la valoración de los parámetros antropométricos en nuestra poblacion: indice adiposo-muscular, indices ponderales y tablas percentiles de los datos antropometricos útiles en una valoración nutricional (New norms and advice in the valuation of the anthropometric parameters in our population: fat-muscle index, ponderal indices and percentile scores of the anthropometric data used in an evaluation of nutritional status). Med Clin (Barc) 91, 223-236.

Anthony H, Bines J, Phelan P \& Paxton S (1998) Relation between dietary intake and nutritional status in cystic fibrosis. Arch Dis Child 78, 443-447.

Arija V, Salas-Salvadó J, Fernández-Ballart J, Serra L \& Aranceta J (2001) Necesidades energéticas. In Guías Alimentarias para la Población Española (In Spanish) pp.345-351 [Sociedad Española de Nutrición Comunitaria, editor]. Madrid: IM\&C SA.

Beckles WN, Elliot TM \& Everard ML (2003) n3 Fatty acids (from fish oils) for cystic fibrosis (Cochrane Methodology Review). In The Cochrane Library, issue 4, Chichester, UK: John Wiley \& Sons Ltd.

Benabdeslam H, Garcia I, Bellon G, Gilly R \& Revol A (1998) Biochemical assessment of the nutritional status of cystic fibrosis patients treated with pancreatic enzyme extracts. Am J Clin Nutr 67, 912-918.

Bhalla M, Turcios N, Aponte V, Jenkins M, Leitman BS, McCauley DL \& Naidich DP (1991) Cystic fibrosis: scoring system with thinsection CT. Radiology 179, 783-788.

Carlstedt-Duke J, Bronnegard M \& Strandvik B (1986) Pathological regulation of arachidonic acid release in cystic fibrosis: the putative basic defect. Proc Natl Acad Sci USA 83, 9202-9206.

Christophe A \& Robberecht E (2001) Directed modification instead of normalization of fatty acid patterns in cystic fibrosis: an emerging concept. Curr Opin Clin Nutr Metab Care 4, 111-113.

Christophe A, Robberecht E, Franckx H, De Baets F \& van de Pas M (1994) Effect of administration of gamma.linolenic acid on the fatty acid composition of serum phospholipids and cholesteryl esters in patients with cystic fibrosis. Ann Nutr Metab 38, 40-47.

Cystic Fibrosis Foundation (1997) Clinical practice guidelines for cystic fibrosis. Bethesda, MD: Cystic Fibroais Foundation. 
De Vizia B, Raia V, Spano C \& Pavlidis C (2003) Effect of an 8month treatment with 3 fatty acids (eicosapentanoic and docosahexaenoic) in patient with cystic fibrosis. $J$ Parenter Enteral Nutr 27, 52-57.

Diabetes and Nutrition Study Group of the Spanish Diabetes Association (2004) Diabetes Nutrition and Complications Trials trends in nutritional pattern between 1993 and 2000 and targets of diabetes treatment in a sample of Spanish people with diabetes. Diabetes Care 27, 984-987.

Freedman SD, Blanco PG, Zaman MM, et al. (2004) Association of cystic fibrosis with abnormalities in fatty acid metabolism. $N$ Engl J Med 350, 560-569.

Freedman SD, Katz MH, Parker EM, Laposata M, Urman MY \& Alvarez JG (1999) A membrane lipid imbalance plays a role in the phenotypic expression of cystic fibrosis in cftr -/- mice. Proc Natl Acad Sci USA 96, 13395-14000.

García-Almeida JM, González-Romero E, Olveira G, MartínezAlfaro B, Esteva I, Dobarganes M \& Soriguer F (2001) Nutritional study of the 'Bajo Guadalhorce'. Clin Nutr 20, Suppl. 3, 72.

Kawchak DA, Zhao H, Scanlin TF, Tomezsko JL, Cnaan A \& Stallings VA (1996) Longitudinal, prospective analysis of dietary intake in children with cystic fibrosis. J Pediatr 129, 119-129.

Lai HC, Kosorok MR, Laxova A, Davis LA, FitzSimmon SC \& Farrell PM (2000) Nutritional status of patients with cystic fibrosis with meconium ileus: a comparison with patients without meconium ileus and diagnosed early through neonatal screening. Pediatrics 105, 53-61.

Lepage G, Yesair DW, Ronco N, Champagne J, Bureau N, Chemtob S, Berube D \& Roy CC (2002) Effect of an organized lipid matrix on lipid absorption and clinical outcomes in patients with cystic fibrosis. J Pediatr 141, 178-185.

Lloyd-Still JD, Bibus DM, Powers CA, Johnson SB \& Holman RT (1996) Essential fatty acid deficiency and predisposition to lung disease in cystic fibrosis. Acta Paediatr 85, 1426-1432.

Mataix J (1995) Tabla de Composición de Alimentos Españoles, 2nd ed. (In Spanish) Granada, Spain: Servicio de Publicaciones de la Universidad de Granada (Granada University Publications Service).

Mora I, Orejas G, Bousoño C, Cue R, Ramos E \& Crespo M (1996) Valoración del estado nutricional en un grupo de pacientes con fibrosis quística (Nutritional status assessment in a group of cystic fibrosis patients). An Esp Pediatr 44, 40-44.

Moreiras O, Carbajal A \& Cabrera ML (1992) La Composición de los Alimentos. (In Spanish) Madrid: Eudema SA.

Parsons HG, O'Loughlin EV, Forbes D, Cooper D \& Gall D (1988) Supplemental calories improve essential fatty acid deficiency in cystic fibrosis patients. Pediatr Res 24, 353-356.

Picarelli A, Greco M, Di Giovambattista F, Ramazzotti A, Cedrone C, Corazziari E \& Torsoli A (1995) Quantitative determination of faecal fat, nitrogen and water by means of a spectrophotometric technique: near infrared reflectance analysis (NIRA). Assessment of its accuracy and reproducibility compared with chemical methods. Clin Chim Acta 234, 147-156.

Ramsey BW, Farrel PM \& Pencharz P (1992) Nutritional assessment and management in cystic fibrosis: a consensus report. The Consensus Committee. Am J Clin Nutr 55, 108-116.

Roca J, Sanchis J, Agustí Vidal A, Segarra F \& Navajas D (1982) Spirometric reference values for a Mediterranean population. Bull Eur Physiopathol Respir 18, 101-102.

Roulet M, Frascarolo P, Rappaz I \& Pilet M (1997) Essential fatty acid deficiency in well nourished young cystic fibrosis patients. Eur J Pediatr 156, 952-956.

Sanchis J, Casan P, Castillo J, González Mangado N, Palenciano L \& Roca J (1989) Normativa para la espirometría forzada (Norm for the forced spirometer). Arch Bronconeumol 25, 132-142.

Sociedad Española de Nutrición Comunitaria (2001) Guías Alimentarias para la Población Española. (In Spanish) Madrid: IM\&C SA.

Sockrider MM, Swank PR, Seilheimer DK \& Schidlow D (1994) Measuring clinical status in cystic fibrosis: internal validity and reliability of a modified NIH score. Pediatr Pulmonol 17, 86-96.

Soriguer F, Esteva I, Rojo-Martínez G, et al. (2002) Prevalence of diabetes mellitus type LADA in South Spain. Diabetes Res Clin Pract 56, 213-220.

Soriguer F, Rojo-Martinez G, Dobarganes MC, et al. (2003) Hypertension is related to the degradation of dietary frying oils. Am J Clin Nutr 78, 1092-1097.

Soriguer F, Serna S, Valverde E, Hernando J, Martín-Reyes A, Soriguer M, Pareja A, Tinahones F \& Esteva I (1997) Lipid, protein and calorie content of different Atlantic and Mediterranean fish, shellfish and mollusc commonly eaten in the south of Spain. Eur J Epidemiol 13, 451-463.

Strandvik B, Gronowitz E, Enlund F, Martinsson T \& Wahlström J (2001) Essential fatty acid deficiency in relation to genotype in patients with cystic fibrosis. J Pediatr 139, 650-655.

Tomezsko JL, Stallings VA \& Scanlin TF (1992) Dietary intake of healthy children with cystic fibrosis compared with normal control children. Pediatrics 90, 547-553.

Welsh M \& Smith A (1993) Molecular mechanisms of CFTR chloride channel dysfunction in cystic fibrosis. Cell 73, 1251-1254.

Werner A, Bongers MEJ, Bijvelds MJ, de Jonge HR \& Verkade HJ (2004) No indications for altered essential fatty acid metabolism in two murine models for cystic fibrosis. J Lipid Res 45, $2277-2286$.

White H, Morton AM, Peckham DG \& Conway SP (2004) Dietary intakes in adult patients with cystic fibrosis - do they achieve guidelines?" J Cyst Fibros 3, 1-7. 